\title{
SALAM, SHALOM, dan SHANTI: Orientasi Kerukunan Umat Beragama Di Dukuh Caben, Desa Sumbermulyo, Bantul
}

\author{
Ahmad Sugeng Riady \\ Mahasiswa Sosiologi Agama, UIN Sunan Kalijaga \\ Yogyakarta \\ *)Email: ahmadsugengriady@gmail.com
}

\begin{abstract}
ABSTRAK
Artikel ini menjelaskan penelitian kehidupan masyarakat umat beragama di Dukuh Caben, Desa Sumbermulyo, Bantul. Masyarakat di Dukuh Caben, Desa Sumbermulyo terdiri dari tiga golongan agama, yakni Islam, Kristen, dan Hindhu. Ketiganya hidup rukun dan berdampingan. Artikel ini diambil dari data primer berupa wawancara dan observasi, dan data sekunder berupa buku, jurnal, atau media cetak yang relevan dengan topik penelitian. Hasil dari penelitian ini bisa dipetakan menjadi tiga bagian: pertama, kerukunan dalam intern umat beragama meliputi solidaritas antar sesama anggota. Solidaritas sesama anggota menjadi semakin kuat ketika ada kegiatan intern umat beragama. Kedua, kerukunan antar umat beragama yang diwujudkan dalam bentuk kerjasama antara masyarakat Islam, Kristen, dan Hindhu. Dan ketiga, kerukunan antara umat beragama dengan pemerintah. Implementasi ketiga bentuk kerukunan tersebut, bisa mewujudkan keselamatan dan kesejahteraan antara umat beragama di Dukuh Caben, Desa Sumbermulyo.
\end{abstract}

Keyword: Kerukunan, Dukuh Caben, Keselamatan Dan Kesejahteraan

\section{PENDAHULUAN}

Dalam Kamus Besar Bahasa Indonesia, agama merupakan ajaran atau sistem yang mengatur tata keimanan (kepercayaan) dan peribadatan kepada Tuhan Yang Mahakuasa serta tata kaidah yang berhubungan dengan pergaulan antar manusia dan manusia dengan lingkungannya. Sedangkan dalam pengertian tata bahasa, agama berasal dari bahasa sansekerta yaitu $a$ (tidak) dan gama (kacau). Jika disatukan memiliki pengertian "tidak kacau". Sedangkan sumber lain menyebutkan bahwa agama disebut juga ugama dan igama. Menurut sumber tersebut, kata "agama" berasal dari kata a dan gama atau dari kata agam. Sumber ini menerangkan bahwa asal kata agama itu dari aqama. Dan jika disebut igama adalah dari kata iqamah, mashdar dari agama yang bermakna mendirikan. Sementara itu ugama berasal dari lughat awam, yang menyebut kasrah dengan dhammah sebagaimana hal tersebut didengar dari orangorang awam berkebangsaan Arab. ${ }^{1}$

Dari pengertian tersebut, agama memberikan pengaruh yang positif terhadap kehidupan umat manusia. Agama bisa membuat kehidupan menjadi tidak kacau, selamat dari musibah baik di dunia maupun nanti dikehidupan setelah dunia. Begitupun manusia juga memberi dampak yang positif terhadap agama. Dengan dianut, dipelajarai, dan diamalkan oleh manusia, agama akan bisa terus eksis di dunia. Sebab, agama bukan subjek yang bisa berdiri sendiri, baik agama samawi maupun

1 Rizem Aizid, Sejarah Peradaban Islam (Yogyakarta : Diva Press, 2015), hlm. 16 
agama ardhi. Karena sebaik apapun bentuk agama, jika tidak ada yang menganut, mempelajari, dan mengamalkan maka akan hilang.

Di Indonesia sendiri, negara yang terkenal dengan sebutan pluralis. Tidak hanya dalam bidang suku, bahasa, namun juga dalam bidang agama, terdapat enam agama dan ratusan aliran kepercayaan yang tumbuh subur. ${ }^{2}$ Masing-masing agama dan aliran kepercayaan mempunyai pengikut sekaligus wilayah yang menjadi basisnya. Misalnya Agama Hindhu yang mayoritas penganutnya terpusat di Bali. Meskipun ada juga penganut Agama Hindhu yang berada di luar Bali, namun itu hanya beberapa. Kemudian penganut aliran kepercayaan Sunda Wiwitan yang mayoritas terpusat di daerah Cikeusik dan daerah sekitarnya. Jika diperinci lagi, misalnya Agama Islam yang masuk dalam Nahdlatul 'Ulama, maka basis massanya berada di daerah Jawa Timur, begitupun seterusnya.

Banyaknya agama dan beragamnya aliran kepercayaan di Indoensia memiliki dampak positif dan negatif. Dampak positifnya, Negara Indonesia dipandang oleh dunia sebagai negara yang memiliki khazanah di bidang religius yang beraneka ragam. Out-putnya, bisa menarik banyak orang-orang dari luar negeri untuk mempelajari keragaman agama yang ada di Indonesia (bagi peneliti dan kalangan

2 Hamidah, "Strategi Membangun Kerukunan Umat Beragama", Jurnal Wardah, Vol. 17, No. 2, JuliDesember 2016, hlm. 130 akademisi). Selain itu, juga bisa dijadikan sebagai sarana hiburan dan objek wisata spiritual untuk menarik wisatawan mancanegara. Dampak negatif yang rentan dari beraneka ragamnya agama dan aliran kepercayaan adalah rawan terjadinya konflik. $^{3}$ Oleh karena itu, mencapai kerukunan dalam rangka menuju keselamatan perlu untuk dibahas sekaligus diimplementasikan dalam sendi-sendi kehidupan.

Baru-baru ini, Indonesia mengalami konflik politik yang menjurus dalam konflik agama. Kunjungan yang dilakukan oleh mantan Gubernur Jakarta, Bapak Basuki Cahaya Purnama (Ahok) di Kepulauan Seribu, Jakarta dianggap telah menistakan Agama Islam. Sebab dalam kunjungannya tersebut, beliau mengutip ayat Al-Qur'an, surat Al-Maidah 51 sekaligus menjelaskan kepada masyarakat agar tidak tertipu dengan pemimpin yang menggunakan legitimasi agama. Akhirnya banyak organisasi massa Islam yang memprotes tindakan Bapak Ahok tersebut. Muncullah berbagai gerakangerakan yang mengupayakan dan mendesak agar Bapak Ahok dihukum. ${ }^{4}$

Pengaruh yang ditimbulkan dari gerakan tersebut merambah pada konflik agama. Penganut Agama Islam berhadapan dengan

\footnotetext{
${ }^{3}$ Makhrus Dkk, Pancasila Dan Kewarganegaraan (Yogyakarta: Pokja Akademik Uin Sunan Kalijaga, 2005), hlm. 5

${ }^{4}$ Kaleidoskop 2016: "Timeline" Penetapan Ahok sebagai terdakwa Penodaan Agama dalam Kompas.com ditulis pada hari Rabu, 14 Desember 2016 jam 07.03 WIB. Dikutip pada tanggal 25 Juni 2018.
} 
penganut Agama Kristen dan pendukung Agama Kristen. Bahkan sampai ada masjid yang terang-terangan menolak untuk dijadikan tempat sholat jenazah bagi pendukung Bapak Ahok. Aktivitas beragama paska gerakangerakan tersebut menjadi lebih tegang. Sesama umat Islam sendiri saling mencurigai, terlebih lagi dengan umat Agama Kristen. Akhirnya secara tidak langsung, agama dijadikan sebagai alat untuk memusuhi sesama umat beragama lainnya, bukan sebagai sarana melegitimasi kerukunan dalam rangka mencapai keselamatan.

Oleh karena itu, artikel ini ditulis sebagai upaya untuk mencari bentuk perilaku umat beragama yang lebih luwes paska berbagai gerakan yang membuat umat beragama jadi tegang. Keluwesan yang dimaksud adalah saling menghormati dan menyayangi baik sesama maupun antar umat beragama. Peneliti memilih objek penelitian yang terdapat di Dukuh Caben, Desa Sumbermulyo, Bantul. Di Dukuh Caben terdapat tiga agama, yakni Islam, Kristen, dan Hindhu. Ketiganya saling bekerja sama sehingga mampu menciptakan kehidupan yang kondusif.

Atas dasar itulah sehingga judul artikel ini berjudul SALAM, SHALOM, dan SHANTI; Orientasi Kerukunan Umat Beragama Di Dukuh Caben, Desa Sumbermulyo, Bantul. Judul tersebut dipilih sebagai tujuan dari perilaku umat beragama.
Salam mempunyai arti kedamaian dan kesejahteraan. Kata ini berasal dari akar kata yang sama dengan kata Ibrani, yakni Shalom, artinya keselamatan. ${ }^{5}$ Sedangkan Shanti meskipun berbeda dari akar katanya, namun memiliki arti yang sama yakni, keselamatan dan kedamaian. Jadi orientasi perilaku beragama umat manusia adalah untuk mencapai tujuan keselamatan dan kedamaian, baik di dunia maupun di akhirat.

Penelitian ini menggunakan kerangka teori Trilogi Kerukunan yang meliputi kerukunan intern umat beragama, kerukunan antar umat beragama, dan kerukunan antara umat bergama dan pemerintah. ${ }^{6}$ Teori tesebut pada mulanya digagas oleh Bapak Mukti Ali (Bapak Perbandingan Agama Indonesia) yang dikenal dengan agree in disagreement pada Forum Symposium di Goethe Institut, Jakarta. Kemudian konsep agree in disagreement tersebut diterjemahkan dalam Trilogi Kerukunan.

Adapun beberapa penelitian terdahulu yang mempunyai relevansi dengan topik penelitian yakni penelitian yang dilakukan oleh Ahmad Sodli, dengan judul Kerukunan Umat Beragama di Provinsi Nusa Tenggara Timur

${ }^{5}$ Nurhadi dan Izzuddin Washil(penj), Charles Kimball; Kala Agama Jadi Bencana, (Bandung : Mizan Pustaka, 2013), hlm. 292

6 Khairah Husin, "Peran Mukti Ali dalam Pengembangan Toleransi Antar Agama di Indonesia", Jurnal Ushuluddin, Vol. XXI, No. 1, Januari 2014, hlm. 105 
(NTT). ${ }^{7}$ Penelitian ini difokuskan di tiga kota/kabupaten, yakni Kota Kupang, Kabupaten Timor Tengah Selatan, dan Kabupaten Timor Tengah Utara. Penelitian ini membahas tentang relasi antar umat beragama, yakni umat Agama Islam, Kristen Protestan, dan Kristen Katolik. Masing-masing agama memiliki tempat peribadatan dan kegiatan sosial-keagamaan.

Relasi yang terjalin antar ketiga umat agama ini dibedakan dalam bentuk kerjasama dan konflik. Bentuk kerjasama yang terjalin yakni pembangunan tempat ibadah, perayaan hari besar agama, dan dalam hal politik. Sedangkan konflik yang terjadi disebabkan oleh rasa ketidaknyamanan penganut Agama Kristen Protestan dan Katolik dengan adzan yang menggunakan pengeras suara. Sehingga timbul tindakan perusakan tempat ibadah. Selain itu, dalam hal ekonomi banyak penganut Agama Kristen Protestan dan Katolik yang iri dengan penganut Agama Islam. Sedangkan konflik yang timbul antara penganut Agama Kristen Protestan dan Katolik terjadi dalam bidang pendidikan, yakni ketika waktu pendaftaran peserta didik baru.

Ada juga penelitian yang dilakukan oleh Rahmini Hadi dengan judul Pola Kerukunan Umat Beragama di Banyumas. ${ }^{8}$ Penelitian ini menjelaskan tentang kerukunan antar umat

\footnotetext{
${ }^{7}$ Ahmad Sodli, "Kerukunan Umat Beragama di Provinsi Nusa Tenggara Timur(NTT)", Jurnal Analisa, Vol. XVI, No. 01, Januari-Juni 2009, hlm. 64-73

8 Rahmini Hadi, "Pola Kerukunan Umat Beragama di Banyumas", Jurnal Kebudayaan Islam, Vol. 14, No. 1, Januari-Juni 2016, hlm. 66-78
}

beragama di Banyumas yang berbasis pada kebudayaan. Sebab wilayah Banyumas merupakan titik temu antara kebudayaan Majapahit dan Padjajaran, sekaligus bertemunya kebudayaan Yogyakarta dan Sunda. Kerukunan di masyarakat Banyumas disebabkan oleh kuatnya toleransi antar umat beragama. Selain itu, faktor geografis yang masih dalam satu wilayah memudahkan pemerintah dan tokoh masyarakat untuk mencegah konflik serta menanggulangi ketika konflik terjadi. Kedua hal tersebut didukung oleh adanya budaya Banyumasan yang tetap dilestarikan. Tantangan serius yang dihadapi oleh masyarakat Banyumas di era globalisasi yakni berkurangnya minat generasi penerus untuk mempelajari budayanya sendiri. Akibat yang ditimbulkan dalam waktu lama akan muncul konflik antar umat beragama, sehingga mengganggu sendi-sendi kehidupan di wilayah Banyumas.

Selain itu, ada juga penelitian yang dilakukan oleh Hamidah dengan judul Strategi Membangun Kerukunan Umat Beragama. ${ }^{9}$ Penelitian ini menjelaskan cara-cara yang harus ditempuh untuk mencapai tujuan agama berupa peran agama dalam proses pembangunan nasional dan pembinaan kerukunan hidup beragama. Adapun cara-caranya adalah dengan sosialisasi dan inkulturasi nilai-nilai agama serta memfasilitasi berbagai upaya yang

9 Hamidah, "Strategi Membangun Kerukunan Umat Beragama", Jurnal Wardah, Vol. 17, No. 2, JuliDesember 2016, hlm. 123-136 
dilakukan oleh masyarakat untuk menciptakan kerukunan.

Dalam ajaran Agama Islam, manusia diciptakan dengan beragam perbedaan (plural). Bahkan di dalam Al-Qur'an sendiri dijelaskan bahwa tidak boleh ada paksaan untuk menyamakan pandangan dan agama manusia. Begitupun Nabi Muhammad dalam dakwahnya juga tidak memaksakan ajaran-ajaran Agama Islam bagi siapapun yang tidak mau beriman. Nilai dasar yang bisa diambil dari fenomena tersebut adalah perlunya penguatan rasa toleransi dan kerjasama antar umat beragama.

Dari ketiga penelitian yang telah dijelaskan, belum ada penelitian yang membahas tentang orientasi kehidupan yang rukun dan damai antar umat beragama. Oleh karena itu, penelitian ini penting dilakukan untuk mengetahui tujuan toleransi dan kerjasama antar umat beragama. Selain itu, penelitian ini juga berfungsi untuk menambah wacana studi dalam bidang perbandingan agama, sosiologi agama, dan bidang-bidang keilmuan lainnya yang mempunyai relevansi dengan topik penelitian.

\section{METODE}

\section{a. Jenis Penelitian}

Penelitian ini menggunakan jenis penelitian kualitatif deskriptif. Dasar yang menjadi pertimbangannya adalah pertama, metode penelitian kualitatif lebih mudah disesuaikan dengan realitas yang sedang diteliti. Kedua, metode ini memberikan ruang bertemu langsung bagi peneliti untuk berinteraksi langsung dengan objek penelitian. Ketiga, metode ini lebih peka dan lebih bisa menyesuaikan pola-pola perkembangan nilai yang terjadi pada objek penelitian. ${ }^{10}$ Setelah itu, objek penelitian dijelaskan (dideskripsikan) sesuai dengan keadaan yang ada di lapangan.

\section{b. Sumber Data}

Data yang digunakan dalam penelitian ini meliputi dua sumber, yakni data primer dan data sekunder. Data primer diambil dari dua unsur, yakni observasi dan wawancara. Observasi dilakukan di tempat objek yang hendak diteliti, yakni di Dukuh Caben, Desa Sumber Mulyo, Bantul. Kemudian wawancara dilakukan kepada beberapa narasumber yang memiliki relevansi dengan topik penelitian.

Sedangkan sumber sekunder diambil dari studi kepustakaan yang meliputi akses buku-buku yang relevan dengan topik penelitian di berbagai perpustakaan di Yogyakarta. Selain itu, pencarian hasil penelitian-penelitian terdahulu dari berbagai jurnal yang mempunyai relevansi dengan topik penelitian.

\section{c. Waktu dan Tempat Penelitian}

Penelitian ini dimulai pada tanggal 27 Februari 2018 - 30 Maret 2018. Adapun tempat yang menjadi objek penelitian adalah Dukuh Caben, Desa Sumbermulyo, Bantul.

\section{HASIL DAN PEMBAHASAN}

10 Lexy Moleong, Metodologi Penelitian Kualitatif, (Bandung : Remaja Rosda Karya, 2000), hlm. 05 
1. Selayang Pandang Dukuh Caben, Desa Sumbermulyo, Bantul

Dukuh Caben merupakan Dukuh ke sebelas dari enam belas Dukuh yang ada di Desa Sumbermulyo. Secara geografis, di sebelah timur berbatasan dengan Dukuh Mejing, di sebelah barat berbatasan dengan Dukuh Gambuhan, di sebelah selatan berbatasan dengan Dukuh Sribit, dan di utara berbatasan dengan Dukuh Blumbungan. Dukuh Caben ini memiliki enam Rukun Tetangga.

Mayoritas mata pencaharian penduduk di Dukuh Caben yakni bertani. Namun, kebanyakan petani yang ada di dukuh Caben kurang sejahtera. Karena banyak petani yang hanya menggarap sawah orang lain, bukan sawah miliknya sendiri (sistim maro). Meskipun ada juga yang memiliki sawah sendiri. Ada sebagaian warga yang berprofesi sebagai pembuat patung rohani. Profesi ini yang menjadi ciri khas bagi Dukuh Caben. Selain itu ada juga yang berprofesi sebagai pengrajin batok kelapa.

Pendidikan masyarakat di Dukuh Caben kebanyakan lulusan Sekolah Menengah Kejuruan. Sebagian kecil ada yang sampai ke perguruan tinggi, sebagian hanya lulusan Sekolah Menengah Pertama, dan ada juga yang tidak melanjutkan hanya sampai di Sekolah Dasar. Faktor yang mempengaruhi pendidikan di Dukuh Caben antara lain kekurangan biaya untuk melanjutkan pendidikan ke jenjang yang lebih tinggi, selain itu lebih tertarik dalam bidang pekerjaan, yakni menjadi tukang pembajak sawah.

\section{Kerukunan Intern Umat Beragama} Masyarakat di Dukuh Caben melaksanakan berbagai kegiatan keagamaan setiap minggu dan bulan. Dari umat islam sendiri, kegiatan peribadatan di masjid dan mushola tetap dilaksanakan setiap harinya. Sholat lima waktu, peringatan hari-hari besar islam seperti peringatan maulid nabi, peringatan isro' mi'roj nabi, dan peringatan di bulan muharrom.

Selain terpusat di tempat peribadatan (masjid dan musholla), kegiatan umat beragama islam juga dilaksanakan keliling dari satu rumah ke rumah yang lainnya, yaitu pengajian. Seperti yang diungkapkan oleh Bapak Samoyo, "Disini kalau umat islamnya ada kegiatan mas setiap minggunya. Ya kayak di RT 01 sampai RT 04. Itu setiap minggu melaksanakan pengajian." ${ }^{11}$ Kegiatan tersebut selain bertujuan untuk bidang peribdatan, juga digunakan sebagai sarana untuk mempererat tali persaudaraan sesama umat islam.

Bagi umat Kristen, kegiatan peribadatannya dilaksanakan di sebuah gereja yang terletak di dukuh tetangga. Penganut agama Kristen yang terdapat di Dukuh Caben adalah Kristen Katolik. Adapun kegiatan bulanan yang dilaksanakan adalah kegiatan bakti sosial. Bakti sosial diwujudkan dalam

${ }^{11}$ Wawancara dengan Bapak Samoyo (54) pada tanggal 03 Maret 2018 di Dukuh Caben, Desa Sumbermulyo 
bentuk kegiatan bersih-bersih rumah dan sekitarnya.

Sedangkan bagi penganut agama Hindhu, kegiatannya cenderung agak pasif. Seperti yang diungkapkan oleh Ibu Ayu, "kalau penganut Agama Hindhu disini agak kurang aktif mas. Ya mungkin karena hanya sedikit. Disini yang beragama Hindhu hanya sekitar 3 kalau tidak 4 rumah mas, itupun menyebar." ${ }^{12}$ Dari pernyataan tersebut, penganut Agama Hindhu di Dukuh Caben hanya sebagai minoritas.

\section{Kerukunan Antar Umat Beragama}

Wujud kerukunan antar umat beragama di Dukuh Caben, Desa Sumbermulyo terjadi dalam kegiatan malam tirakatan 17 Agustus. Malam tirakatan ini biasanya dilaksanakan di 5 tempat, yakni di RT 01 sampai 05, sedangkan RT 06 gabung jadi satu di RT 05. Kegiatannya diisi dengan doa bersama. Doanya dilakukan dalam bentuk dua macam, yakni doa umat Islam dan doa Kristen Katolik. Tujuannya agar masyarakat di Desa Sumbermulyo, khususnya di Dukuh Caben bisa lebih baik dari tahuntahun sebelumnya.

Dalam bidang politik, kerukunan antar umat beragama di Dukuh Caben terjalin cukup baik. Hal ini sesuai dengan pernyataan dari Bapak Rantoyo selaku ketua Dukuh Caben, Desa Sumbermulyo. "Saya dulu mas, waktu ada pemilihan ketua dukuh. Tahun 2006 kalau

${ }^{12}$ Wawancara dengan Ibu Ayu (38) pada tanggal 13 Maret 2018 di Dukuh Caben, Desa Sumbermulyo tidak salah, habis sini terkena gempa. Saya itu maju malah didukung oleh tokoh Agama Islam mas. Lawong saya minta izin ke Romo malah tidak dibolehkan. Yawislah, karena banyak orang yang ingin saya maju, akhirnya saya maju juga mas. Pada waktu itu, calonnya ada lima mas. Tiga dari penganut Agama Islam, dua dari Katolik, salah satunya saya.",13

Dalam hal politik, masyarakat di Dukuh Caben tidak menganut kepatuhan buta dalam memilih pemimpin sebagai ketua dukuh. Tidak mesti orang islam memilih sesama orang islam. Terbukti dari pernyataan Bapak Rantoyo tersebut, bahwa beliau sendiri maju justru yang mendukung adalah tokoh dari umat islam sendiri. Bahkan beliau jadi ketua Dukuh Caben yang mayoritas masyarakatnya menganut Agama Islam.

Selain dalam bidang sosial berupa malam tirakatan dan bidang politik, kerukunan antar umat beragama di Dukuh Caben juga terjadi di bidang ekonomi. Mata pencaharian utamanya adalah bertani, dan mayoritas yang memiliki tanah pertanian adalah orang islam. Namun ada juga sebaian kecil dari umat kristen katolik. Meskipun begitu, ketika musim tanam dan musim panen tiba, semua masyarakat yang profesinya petani tanpa terkecuali saling bahumembahu. Terkadang orang islam menjadi buruh bagi pemilik sawah orang kristen katolik, begitupun sebaliknya.

13 Wawancara dengan Bapak Rantoyo (54), Ketua Dukuh pada tanggal 20 Maret 2018 di Dukuh Caben, Desa Sumbermulyo 


\section{Kerukunan Umat Beragama dengan} Pemerintah

Masing-masing padukuhan di Desa Sumbermulyo mendapatkan anggaran delapan juta untuk pembangunan fisik, termasuk Dukuh Caben. Pembangunan fisik berupa pembangunan jalan yang rusak, perawatan jalan-jalan yang telah rusak. Selain itu, juga digunakan untuk kerja bakti membersihkan tempat-tempat kumuh.

Dukuh Caben juga mempunyai embung. Embung ini pada awalnya dikelola oleh pihak Dukuh dibantu dengan Pemerintah Desa. Namun karena lebih banyak mengalami kerugian, embung ini untuk sementara waktu tidak lagi dikelola seperti biasanya. Embung ini biasanya digunakan sebagai tempat pemancingan dan tempat rekreasi. Meskipun sudah tidak dikelola lagi, keberadaan embung ini masih tetap ada.

Dari Pemerintah Desa sendiri, melalui padukuhan juga menyalurkan berbagai bantuan. Misalnya pembagian kartu. Kartu ini nantinya bisa ditukarkan dengan barang sembako, seperti beras dan telur. Ada juga penyewaan kios-kios. Semua warga berhak untuk mendapatkan fasilitas yang diberikan oleh Desa melalui padukuhan, termasuk padukuhan Caben.

Kerja sama lainnya antara masyarakat beragama dengan pemerintah terjadi ketika ada acara bersih desa. Dari desa biasanya mengintruksi ke berbagai padukuhan untuk menyiapkan hasil panen dibentuk seperti tumpeng raksasa. Tumpeng raksasa dari berbagai dukuh ini diarak mengitari Desa Sumbermulyo, dan berakhir di lapangan Desa Sumbermulyo. Di lapangan tersebut, tumpeng dimakan bersama-sama. Tujuannya sebagai wujud rasa syukur masyarakat Desa Sumbermulyo atas hasil panen yang telah diberikan oleh Tuhan. Kegiatan ini biasanya dilaksanakan setiap awal tahun baru.

\section{Orientasi Kerukunan}

Dimasa globalisasi, kerukunan antar umat beragama menjadi hal penting untuk dibahas. Dunia global yang memiliki ciri akses cepat informasi dan komunikasi dari berbagai arah, individual, dan konsumtif, membuat kerukunan antara umat agama yang satu dengan umat agama lain menjadi rawan terpecah belah. Oleh karena itu, media-media, baik sosial maupun cetak seharusnya bersinergi dengan pemerintah dan masyarakat dalam memberikan berbagai informasi yang bermanfaat. $^{14}$ Tujuannya untuk mencegah dan menghindari konflik antar umat beragama.

Konflik-konflik yang terjadi di Indonesia seperti di Ambon dan Poso, antara masyarakat yang menganut Agama Islam dan Kristen masih terasa jelas dalam memori bangsa Indonesia. Selain itu, konflik luar negeri, mulai dari masa klasik yakni perang salib sampai hari ini yang masih terjadi yakni antara Palestina

${ }^{14}$ Zuly Qodir, Sosiologi Agama; Esai-Esai Agama di Ruang Publik, (Yogyakarta : Pustaka Pelajar, 2011), hlm. 199 
dan Israel. $^{15}$ Semua konflik-konflik tersebut dipelajari oleh berbagai pihak untuk mengetahui sebab dan dicarikan solusi pemecahannya.

Di Dukuh Caben sendiri, kerukunan dalam masyarakatnya rawan terancam perpecahan. Sebab, konflik antar agama bisa saja terjadi. Baik antara umat Islam dengan Kristen Katolik, umat Islam dengan Hindhu, atau umat Kristen Katolik dengan Hindhu. Beberapa tahun lalu, pernah terjadi konflik di Dukuh Caben. "Dulu disini pernah ada masalah mas. Jadi di sebelah kanan musholla itu ada orang Katolik. Lha, setiap hari, lima waktu orang Islam kan melaksanakan sholat. Sebelume sholat kan adzan dulu. Nah itu, menurut orang Katolik itu brisik. Akhire ditulisi dipintu gerbange. Intinya kalau beribadah jangan berisik. Ya akhire rame mas. Sampek ke kantor desa kok. Tapi untungnya tidak ada sampai ada pertumpahan darah."16

Oleh karena itu, kerukunan menjadi nilai penting yang harus dipertahankan oleh seluruh elemen, baik pemerintah maupun masyarakat beragama. Karena dengan mencapai kerukunan, keselamatan di dunia dan akhirat akan bisa tercapai. Intern umat beragama rukun, antar umat beragama rukun, dan umat beragama dengan pemerintah rukun, dengan sendirinya

15 Djam'annuri dkk, Bunga Rampai Sosiologi Agama; Teori, Metode, dan Ranah Studi Ilmu Sosiologi Agama, (Yogyakarta : Diandra Pustaka Indonesia, 2015), hlm. 22

16 Wawancara dengan Bapak Rantoyo (54), Ketua Dukuh pada tanggal 15 Maret 2018 di Dukuh Caben, Desa Sumbermulyo keselamatan dalam berbangsa dan bernegara akan mudah dicapai.

Sedangkan Agama Islam sendiri, perihal kerukunan yang berorientasi pada keselamatan dijelaskan oleh Al-Qur'an dalam surat Al-Baqarah ayat 62 yang artinya "sesungguhnya orang-orang mukmin, orangorang Yahudi, orang-orang Nasrani dan orangorang Shabiin, siapa saja diantara mereka yang benar-benar beriman kepada Allah, hari kemudian dan beramal saleh, mereka akan menerima pahala dari tuhan mereka, tidak ada kekhawatiran bagi mereka, dan tidak (pula) mereka bersedih hati”.

Kerukunan yang terjadi di masyarakat Dukuh Caben, baik intern agama, antar agama, dan umat beragama dengan pemerintah masuk dalam ketegori amal shaleh. Dalam tafsirannya lebih lanjut, amal shaleh yang dimaksud bukan hanya berkaitan dengan bidang peribadatan, melainkan juga bidang-bidang lain, misalnya sosial, pendidikan, ekonomi, dan lain sebagainya. Maka dari itu, kerukunan yang telah tercapai akan membawa kepada keselamatan, baik dunia maupun akhirat. Keselamatan dunia meliputi terhindar dari adanya konflik, sedangkan keselamatan akhirat meliputi mendapat balasan berupa pahala dari Tuhannya.

\section{Kesimpulan}

Masyarakat di Dukuh Caben terdiri dari tiga penganut agama, yakni Islam, Kristen Katolik, dan Hindhu. Kehidupan masyarakat di 
Dukuh Caben lekat dengan kerukunan yang berorientasi keselamatan. Kerukunan yang mengantarkan keselamatan diwujudkan dalam tiga bentuk. Pertama kerukunan intern umat beragama. Di Dukuh Caben, masyarakat penganut agama memiliki kegiatannya masingmasing. Tujuannya untuk mempererat solidaritas sesama anggota. Kedua kerukunan antar umat beragama. Diwujudkan dalam bentuk peringatan hari besar, sosial, dan juga politik pemilihan kepala dukuh. Ketiga kerukunan antar umat beragama dengan pemerintah. Wujudnya berupa bentuk bantuan sosial dan bersih desa. Ketiga bentuk kerukunan ini saling bersinergi, sehingga keselamatan yang menjadi orientasi dari kerukunan bisa diperoleh. Baik keselamatan di dunia maupun keselamatan di akhirat.

\section{DAFTAR PUSTAKA}

Aizid, Rizem Aizid. 2015. Sejarah Peradaban Islam. Yogyakarta : Diva Press

Djam'annuri dkk. 2015. Bunga Rampai Sosiologi Agama; Teori, Metode, dan Ranah Studi Ilmu Sosiologi Agama. Yogyakarta : Diandra Pustaka Indonesia

Hadi, Rahmini. 2016. "Pola Kerukunan Umat Beragama di Banyumas". Jurnal Kebudayaan Islam, Vol. 14, No. 1, Januari-Juni 2016

Hamidah. 2016. "Strategi Membangun Kerukunan Umat Beragama”. Jurnal
Wardah. Vol. 17, No. 2, Juli-Desember 2016

Husin, Khairah. 2014. "Peran Mukti Ali dalam Pengembangan Toleransi Antar Agama di Indonesia". Jurnal Ushuluddin. Vol. XXI, No. 1, Januari 2014

Kaleidoskop 2016: “Timeline” Penetapan Ahok sebagai terdakwa Penodaan Agama dalam Kompas.com ditulis pada hari Rabu, 14 Desember 2016 jam 07.03 WIB Makhrus Dkk. 2005. Pancasila dan Kewarganegaraan. Yogyakarta : Pokja Akademik Uin Sunan Kalijaga

Moleong, Lexy. 2000. Metodologi Penelitian Kualitatif. Bandung : Remaja Rosda Karya

Qodir, Zuly. 2011. Sosiologi Agama; Esai-Esai Agama di Ruang Publik.Yogyakarta :

Pustaka Pelajar

Sodli, Ahmad. 2009. "Kerukunan Umat Beragama di Provinsi Nusa Tenggara Timur(NTT)". Jurnal Analisa. Vol. XVI, No. 01, Januari-Juni 2009

Washil, Nurhadi dan Izzuddin(penj). 2013. Charles Kimball; Kala Agama Jadi Bencana. Bandung : Mizan Pustaka 